\title{
Clinical Outcomes of Thrombolytic Therapy in Patients with Mild Stroke: A Single-center Experience in a Tertiary Care Institution
}

\author{
Hafif İnmeli Hastalarda Trombolitik Tedavinin Klinik Sonuçları: Üçüncü Basamak \\ Sağlık Kurumunda Tek Merkez Deneyimi
}

\author{
(1) Hasan Hüseyin Karadeli, (1) Ruken Şimşekoğlu \\ Istanbul Medeniyet University, Goztepe Prof. Dr. Suleyman Yalçin City Hospital, Clinic of Neurology, Istanbul, Turkey
}

\begin{abstract}
Objective: Mild stroke is used to describe patients with stroke having a National Institutes of Health Stroke Scale (NIHSS) score of 0-6. However, there is still no clear decision regarding the application of intravenous (iv) recombinant tissue plasminogen activator (iv-tPA) to patients who were admitted with an acute ischemic stroke and were in the mild stroke category. This study aimed to analyze data of patients who applied to our stroke center with an acute mild stroke clinic and received iv-tPA treatment and 3-month follow-up.

Materials and Methods: Of 350 patients receiving thrombolytic therapy, 47 (age 69.1 \pm 14.1 , 28 female) patients with mild stroke were included. iv thrombolysis was initiated with a maximum delay of $4.5 \mathrm{~h}$ in all patients. Patients had an NIHSS score of less than 6 . NIHSS scores immediately before starting thrombolytic therapy and scores $24 \mathrm{~h}$ after treatment were recorded. Modified rankin scale scores (mRS) at admission and at 1 and 3 months were recorded.

Results: The NIHSS scores of patients who received tPA decreased significantly after the treatment $(\mathrm{p}=0.001)$. The mRS scores of the patients at the first and third months were significantly decreased according to the mRS scores when they entered the treatment $(\mathrm{p}=0.001)$.

Conclusion: This study highlights the efficacy of iv-tPA in patients with acute ischemic stroke and mild symptoms and demonstrates the low-risk profile of this therapy.
\end{abstract}

Keywords: Mild stroke, NIHSS, modified rankin scale, thrombolytic treatment, iv-tPA

$\ddot{O} \mathbf{z}$

Amaç: "Hafif inme" deyimi Ulusal Sağlık Enstitüleri İnme Ölçeği (NIHSS) skoru 0-6 arasında olan hastaları belirtmek için kullanılmaktadır. Akut iskemik inme ile başvuran ve hafif inme kategorisinde olan hastalara intravenöz (iv) rekombinant doku plazminojen aktivatörünün (iv-tPA) uygulanmasına ilişkin hala net bir karar yoktur. Çalışmamızda akut hafif inme kliniği ile inme merkezimize başvuran ve iv-tPA tedavisi alan hastaların verilerini ve üç aylık takiplerini incelemeyi amaçladık.

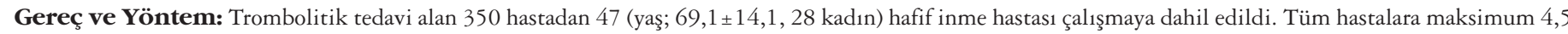
saat gecikmeyle iv tromboliz başlandı. Hastaların NIHSS skoru 6'dan düşüktü. Trombolitik tedaviye başlamadan hemen önceki NIHSS skorları ve tedaviden 24 saat sonraki skorlar kaydedildi. Başvuruda, 1. ve 3. aylarda modifiye rankin skoru puanları (mRS) kaydedildi.

Bulgular: Tedavi sonrası tPA alan hastaların NIHSS skorlarının anlamlı şekilde azaldığı görüldü ( $\mathrm{p}=0,001)$. Hastaların 1 . ve 3 . ay mRS skorları tedaviye başladıklarındaki mRS skorlarına göre istatistiksel olarak anlamlı azaldı $\breve{g}_{1}$ izlendi $(\mathrm{p}=0,001)$.

Sonuç: Bu çalışmadaki veriler hafif inme grubundaki akut iskemik serebrovasküler olay geçiren hastalarda verilen iv-tPA tedavisinin etkinliğini, uzun dönem engelliliği önemli ölçüde azalttı̆̆ını göstermektedir.

Anahtar Kelimeler: Hafif inme, NIHSS, modifiye rankin skoru, trombolitik tedavi, iv-tPA

Address for Correspondence/Yazışma Adresi: Ruken Şimşekoğlu MD, Istanbul Medeniyet University, Goztepe Prof. Dr. Suleyman Yalçin City Hospital, Clinic of Neurology, Istanbul, Turkey

Phone: +90 5337303097 E-mail: rukenmermut@gmail.com ORCID: orcid.org/0000-0002-2127-2545

Received/Geliss Tarihi: 22.03 .2021 Accepted/Kabul Tarihi: 11.07 .2021

${ }^{\circ}$ Copyright 2021 by Turkish Neurological Society

Turkish Journal of Neurology published by Galenos Publishing House. 


\section{Introduction}

The National Institute of Health Stroke Scale (NIHSS) is frequently performed for scoring examination data performed before thrombolytic therapy in patients with acute stroke. Mild stroke is used to describe patients with stroke having an NIHSS of 0-6. However, no clear decision has been established regarding the application of intravenous recombinant tissue plasminogen activator (iv-tPA) to patients who were admitted with an acute ischemic stroke and in the mild stroke category. At present, most patients with ischemic stroke do not receive iv-tPA treatment because they do not apply to hospitals within the required time frame (1). Community-based studies have shown that $54.6 \%$ of patients who can apply within the first $4.5 \mathrm{~h}$ are in the mild stroke category (2). The recurrent stroke rates of patients with mild stroke range from $10 \%$ to $20 \%$ in the first 3 months, and this recurrence was more frequent in a few days after the first stroke $(3,4)$. Thrombolytic therapy (iv-tPA) is one of the most effective treatments in patients with acute ischemic stroke $(5,6,7)$, and iv-tPA treatment can improve the condition of the patients by providing reoxygenation in the penumbra tissue with thrombolysis given in the acute phase and by protecting the patient from recurrent strokes that can be followed in the first days after stroke $(5,6)$. The presence of symptoms that often cause disability was considered an indication of providing iv-tPA to patients with mild stroke, but this criterion brings about many relative conditions and a large gray zone in the clinic (8). Thus, patients who need it or whose condition may worsen in the later hours cannot receive thrombolytic therapy. Although the NIHSS is currently used as the most useful patient assessment scale for acute stroke, it may be inadequate in evaluating patients with posterior system infarctions and in scoring neurological deterioration $(9,10,11)$. In addition, the NIHSS may not be sufficient to assess high cortical functions that are impaired or lost in patients with acute stroke (11). Therefore, patients who presented to the hospitals with acute mild stroke clinic, who cannot receive iv-tPA because of low NIHSS score, but whose condition may worsen in the clinic in the following hours or days, is considered to have an important medical condition. This study aimed to analyze the data of patients who presented to our stroke center with an acute mild stroke clinic and received iv-tPA treatment and 3-month follow-up.

\section{Material and Methods}

The study protocol was approved by the Local Ethics Committee of S.B. Istanbul Medeniyet University Göztepe Prof. Dr. Suleyman Yalçin City Hospital (decision no: 2021/0108, date: 10.02.2021). Patients provided consent to participate in the study.

Patients with mild stroke who were admitted to Göztepe Prof. Dr. Süleyman Yalçin City Hospital Stroke center between 2018 and 2020 with an acute ischemic stroke and treated with iv-tPA were retrospectively screened. In this study, 350 patients were screened retrospectively, and 50 patients with mild stroke receiving thrombolytic therapy were identified. Finally, 47 patients were included in the study because they continued their longterm follow-ups in our outpatient clinic. In all patients, iv-tPA was initiated with a maximum delay of $4.5 \mathrm{~h}$. Patients had NIHSS scores $<6$. Patients who underwent mechanical thrombectomy and those with large-vessel occlusion were excluded from the study. Patients who discontinue follow-up in our hospital and did not visit the outpatient clinic subsequently were not included in the study because of incomplete data. The NIHSS scores immediately before starting thrombolytic therapy and at $24 \mathrm{~h}$ after treatment were recorded. Modified rankin scale scores (mRS) at admission and at 1 and 3 months were recorded. Age, gender, smoking and alcohol habits, diabetes mellitus, hypertension, hyperlipidemia, atrial fibrillation, coronary artery disease, and previous ischemic stroke histories were taken as risk factors for stroke. The use of antiaggregants or anticoagulants during stroke was determined. Strokes were classified as total anterior circulation infarct, partial anterior circulation infarct, lacunar infarct, and posterior circulation infarct according to the Oxfordshire Community Stroke Project classification. Moreover, stroke etiology was identified according to Bamford classification. Patients who had hemorrhagic transformation after thrombolytic therapy were identified.

\section{Statistical Analysis}

The level of statistical significance was set as $\mathrm{p}<0.05$, and SPSS (ver. 23) program was used for statistical analyses. Descriptive analyses (numbers and rates) are shown in the tables. The post-hoc test was used to compare the NIHHS and MRS scores.

\section{Results}

This study included 47 patients with mild stroke (age, $69.1 \pm 14.1$ years, 28 female) from 350 patients who received ivtPA. The characteristics of the patients included in the study are given in Table 1. The NIHSS of the patients who received iv-tPA decreased significantly after the treatment $(\mathrm{p}=0.001)$. Ischemic stroke risk factors and etiological parameters of the patients are given in Table 1. Hemorrhagic transformation was observed in 3 of 47 patients after iv-tPA treatment. On neurological examination, only one patient demonstrated deterioration of neurological status after hemorrhagic transformation. Furthermore, 23 (49\%) patients had partial anterior system infarction, 8 had lacunar syndrome, and 16 had posterior system infarction. The NIHSS scores one admission and at $24 \mathrm{~h}$ and mRS scores on admission and at 1 month and 3 months are given in Table 2. The mRS scores at 1 month and 3 months were significantly decreased compared with the mRS scores at the start of treatment $(p=0.001)$.

\section{Discussion}

This study demonstrated that iv-tPA treatment effectively influences both NIHSS and mRS scores in patients with acute mild stroke. This study suggests that patients with mild stroke should receive iv-tPA treatment. Our findings show that the conditions of patients who received iv-tPA clinically improved after treatment. The mRS scores at 1 month and 3 months significantly improve. Most of the patients with acute stroke who received iv-tPA recovered completely within 3 months.

The current stroke guidelines reveal that the optimal treatment for patients with acute minor non-disabling stroke within the first $4.5 \mathrm{~h}$ is not yet established. The prognosis of patients who present with mild symptoms that are unlikely to cause disability may worsen within days. Symptoms of some stroke patients become apparent in the following hours, and some of the patients experience recurrent strokes in the first few days of illness (12). Reports of low therapeutic strength, uncertain benefit, and risk of hemorrhage may lead clinicians to defer the administration of iv-tPA in these 


\section{Table 1. Patient characteristics}

\begin{tabular}{|c|c|}
\hline Age $($ years $)($ mean $\pm S D)$ & $69.1 \pm 14.1$ \\
\hline $\begin{array}{l}\text { Gender, n }(\%) \\
\text { Female } \\
\text { Male }\end{array}$ & $\begin{array}{l}28(59.6 \%) \\
19(40.4 \%)\end{array}$ \\
\hline $\begin{array}{l}\text { Smoking, n (\%) } \\
\text { Yes } \\
\text { No }\end{array}$ & $\begin{array}{l}15(31.9 \%) \\
32(68.1 \%)\end{array}$ \\
\hline $\begin{array}{l}\text { Risk factors, n (\%) } \\
\text { Diabetes mellitus } \\
\text { Hyperlipidemia } \\
\text { Hypertension } \\
\text { Coronary artery disease } \\
\text { Cerebrovascular disease }\end{array}$ & $\begin{array}{l}22(46.8 \%) \\
28(59.6 \%) \\
38(80.9 \%) \\
15(31.9 \%) \\
4(8.5 \%)\end{array}$ \\
\hline $\begin{array}{l}\text { Electrocardiogram, n (\%) } \\
\text { Atrial fibrillation } \\
\text { Normal sinus rhythm }\end{array}$ & $\begin{array}{l}7(14.9 \%) \\
40(85.1 \%)\end{array}$ \\
\hline $\begin{array}{l}\text { Anticoagulant: Antiplatelet medication, } \mathrm{n}(\%) \text { acid } \\
\text { Acetylsalicylic acid } \\
\text { Clopidogrel } \\
\text { Anticoagulant } \\
\text { No }\end{array}$ & $\begin{array}{l}16(34 \%) \\
3(6.4 \%) \\
1(2.1 \%) \\
27(57.4 \%)\end{array}$ \\
\hline
\end{tabular}

\section{Table 2. Clinical outcomes of patients}

(a) NIHSS and mRS scores

Clinical variables

NIHSS scores (mean \pm SD)

NIHSS on admission

$24^{\text {th }}$ hour NIHSS

mRS scores (mean \pm SD)

mRS on admission

$1^{\text {st }}$ month mRS

$3^{\text {rd }}$ month mRS
Mean scores

$4.17 \pm 1.14$

$1.85 \pm 2.13$

$2.25 \pm 0.76$

$0.68 \pm 1.27$

$0.63 \pm 1.15$
$121.1 \pm 37.6$

$6.7 \pm 1.6$

$57.3 \pm 8.6$

$7(14.9 \%)$

$6(34 \%)$

$3(6.4 \%)$

$1(2.1 \%)$

$27(57.4 \%)$

$3(6.4 \%)$

$44(93.6 \%)$

$(49 \%)$

$8(17 \%)$

\section{(b) Post-hoc test for mRS scores in different visits}

\section{Visits}

Admission - $1^{\text {st }}$ month

Admission - $3^{\text {rd }}$ month

\section{p values}

0.001

0.001

SD: Standard deviation, NIHSS: National Institutes of Health Stroke Scale, mRS: Modified rankin scale

p values

0.001

0.001 
patients (13). Approximately $50 \%$ of patients with acute stroke belong to the mild stroke category, but the thrombolytic treatment of this large stroke population is uncertain (2). In their study, Khatri et al. (14) analyzed the 90-day neurological follow-up data of patients with mild stroke without thrombolytic therapy and found that a significant proportion (29\%) of disability developed within 90 days in patients with mild ischemic stroke.

In their study, Logallo et al. (15) analyzed 1791 patients with acute mild stroke who presented to the stroke center, categorized these patients on whether they received or did not receive iv-tPA, and compared their risks of intracranial hemorrhage. As a result, hemorrhagic transformation developed in three $(1.9 \%)$ patients who received iv-tPA and in $1(0.1 \%)$ patient who did not receive iv-tPA, and no significant risk difference was found between the two groups (15). In the present study, hemorrhagic transformation was observed in 3 of 47 patients, and only one patient experienced neurological deterioration after treatment. In 2019, Haeberlin et al. (16) analyzed the 3-month functional outcomes of 108 patients with mild stroke who received iv-tPA in comparison with 262 patients with mild stroke who received the best medical therapy. As a result, patients who received iv-tPA had experienced complete remission more often of their symptoms $(\mathrm{p}<0.0001)(16)$.

The MULTI STAR study, which was conducted to examine the safety and efficiency of iv-tPA, stated that patients with mild stroke were excluded from thrombolytic therapy because of their risk of cerebral hemorrhage. Moreover, $25-30 \%$ of patients with mild stroke, who were eligible to receive iv-tPA, but whose mild symptoms were not treated, had poor results during follow-up. By contrast, patients with mild stroke who received iv-tPA have low hemorrhage risk and favorable outcomes. The results of the study suggest that the treatment of patients with mild stroke is safe and effective (17).

Similarly, in the present study, hemorrhagic transformation after thrombolytic therapy was observed in only three patients, and the rate is very low. Although the NIHSS is used as the most adequate scale in assessing acute stroke, it has limitations (10). For example, it is inadequate in measuring posterior system infarcts symptoms and high cortical function losses because of cortical infarcts. In our study, two patients had internuclear ophthalmoplegia caused by posterior system infarct, and their NIHSS scores were 0 on admission. In our study, patients with mild stroke who received iv-tPA were found to have significantly improved functional outcomes based on their $\mathrm{mRS}$ scores at 3 months. Likewise, NIHSS calculated with acute stroke symptoms significantly decreased after iv-tPA treatment.

\section{Study Limitations}

Despite the promising results, this study has certain limitations. First, it was a single-center study with a relatively low number of cases. Second, there was no control group. Third, the follow-up period was only 3 months. Future studies with a larger sample size, longer follow-up period, and control group are needed to predict treatment outcomes.

\section{Conclusion}

This study highlights the efficacy of iv-tPA in patients with acute ischemic stroke and mild symptoms and demonstrates the low-risk profile of this therapy.

\section{Ethics}

Ethics Committee Approval: The study protocol was approved by the Local Ethics Committee of S.B. Istanbul Medeniyet University Göztepe Prof. Dr. Suleyman Yalçin City Hospital (decision no: 2021/0108, date: 10.02.2021).

Informed Consent: Patients provided consent to participate in the study.

Peer-review: Externally and internally peer-reviewed.

\section{Authorship Contributions}

Surgical and Medical Practices: H.H.K., R.Ş., Concept: H.H.K., R.Ş., Design: H.H.K., R.Ş., Data Collection or Processing: R.Ş., Analysis or Interpretation: H.H.K., R.Ş., Literature Search: R.S.., Writing: H.H.K., R.Ş.

Conflict of Interest: The authors have not declared any conflict of interest related to this article.

Financial Disclosure: No financial support was received from any institution or person for our study.

\section{References}

1. Del Zoppo GJ, Saver JL, Jauch EC, et al. Expansion of the time window for treatment of acute ischemic stroke with intravenous tissue plasminogen activator. a science advisory from the American Heart Association/American Stroke Association. Stroke 2009; 40:2945-2948.

2. Dhamoon MS, Moon YP, Paik MC, et al. Long-term functional recovery after first ischemic stroke: The Northern Manhattan Study. Stroke 2009; 40:2805-2811.

3. Chandratheva A, Geraghty OC, Rothwell PM, Poor performance of current prognostic scores for early risk of recurrence after minor stroke. Stroke 2011;42:632-637.

4. Johnston SC, Gress DR, Browner WS, et al. Short-term prognosis a er emergency department diagnosis of TIA. JAMA 2000;284:2901-2906.

5. National Institute of Neurological Disorders and Stroke rt-PA Stroke Study Group. Tissue plasminogen activator for acute ischemic stroke. N Engl J Med 1995;333:1581-1587.

6. Cocho D, Belvís R, Martí-Fàbregas J, et al. Reasons for exclusion from thrombolytic therapy following acute ischemic stroke. Neurology 2005;64:719-720.

7. Khatri P, Kleindorfer DO, Devlin T, et al. Effect of alteplase vs aspirin on functional outcome for patients with acute ischemic stroke and minor nondisabling neurologic deficits: The PRISMS randomized clinical trial. JAMA 2018;10;320:156-166.

8. Powers WJ, Rubinstein AA, Ackerson T, et al. Guidelines for the early management of patients with acute ischemic stroke: 2019 update to the 2018 guidelines for the early management of acute ischemic stroke: a guideline for healthcare professionals from the American Heart Association/ American Stroke Association. Stroke 2019;50:344-418.

9. Brott T, Adams HP, Olinger CP, et al. Measurements of acute cerebral infarction: a clinical examination scale. Stroke 1989;20:864-870.

10. Muir KW, Weir CJ, Murray GD, et al. Comparison of neurological scales and scoring systems for acute stroke prognosis. Stroke 1996;27:1817-1820.

11. Williams LS, Yilmaz EY, Lopez-Yunez AM. Retrospective assessment of initial stroke severity with the NIH Stroke Scale. Stroke 2000;31:858-862.

12. Barber PA, Zhang J, Demchuk AM, et al. Why are stroke patients excluded from tPA therapy? An analysis of patient eligibility. Neurology 2001;56:1015-1020.

13. Cheng NT, Kim AS. Intravenous Thrombolysis for Acute Ischemic Stroke Within 3 Hours Versus Between 3 and 4.5 Hours of Symptom Onset. Neurohospitalist 2015;5:101-109.

14. Khatri P, Conaway MR, Johnston KC; Acute Stroke Accurate Prediction Study (ASAP) Investigators. Ninety-day outcome rates of a prospective cohort of consecutive patients with mild ischemic stroke. Stroke 2012;43:560-562. 
15. Logallo N, Kvistad CE, Naess H, et al. Mild stroke: safety and outcome in patients receiving thrombolysis. Acta Neurol Scand Suppl 2014:37-40.

16. Haeberlin MI, Held U, Baumgartner RW, et al. Impact of intravenous thrombolysis on functional outcome in patients with mild ischemic stroke without large vessel occlusion or rapidly improving symptoms. Int J Stroke 2020;15:429-437.
17. Sørensen SB, Barazangi N, Chen C, et al. Generalized safety and efficacy of simplified intravenous thrombolysis treatment (SMART) criteria in acute 1schemic stroke: the MULTI SMART study. J Stroke Cerebrovasc Dis 2016;25:1110-1118. 